\section{E- LOGOS}

ELECTRONIC JOURNAL FOR PHILOSOPHY

ISSN 1211-0442

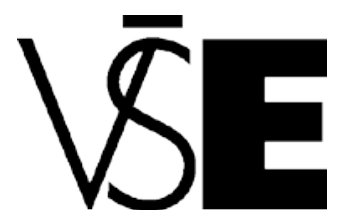

University of Economics Prague

\title{
Obraz a slovo
}

Jiří Vaněk

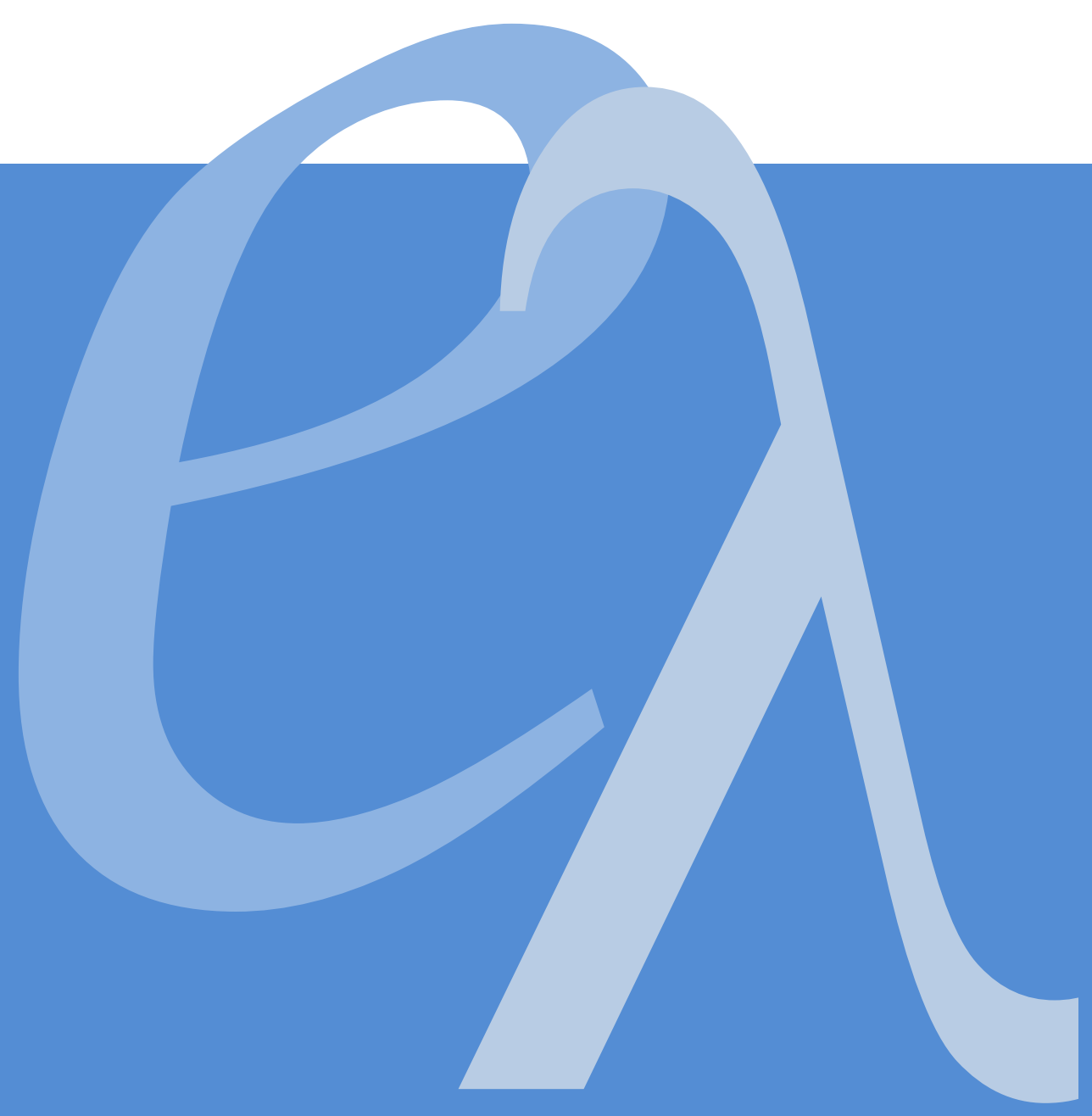




\begin{abstract}
Abstrakt
Studie se zabývá možnými vztahy mezi slovem a obrazem z hlediska myšlenkového obsahu. Tématem jsou odlišné možnosti vyjádření myšleného obsahu slovem, interpretace slova prostřednictvím obrazů a interpretace obrazů slovy. Odlišné významy se objevují, přečteme-li obraz jako typ, metaforu, symbol nebo mýtus. Zvláštní funkci má slovo $\mathrm{v}$ obraze. Ukazují se cesty vymezování významových horizontů lidského světa.
\end{abstract}

Klíčová slova: obraz - slovo - paralelní kontemplace - René Magritte - Zdeněk Mathauser - význam - jazyk - porozumění - pojetí vnímání - zobrazení

\title{
Abstract
}

The essay explains the connections between word and image as seen from the aspect of mental contents. Its theme includes various possibilities to express mental contents as well as the interpretation of words by images and the interpretation of images by words. If we read the image as type, metaphor, symbol or myth, we can find different meanings. The word in image has a specific function in relation to the horizons of meaning in human world.

Key words: image - word - parallel contemplation - René Magritte - Zdeněk Mathauser - meaning - languague - understanding - sensual concept representation 
O tom, že interpretace je všudypřítomná, se přesvědčujeme dnes asi důrazněji než $\mathrm{v}$ dřívějších dobách. Má na tom zásadní podíl nebývalé prolínání věcného a virtuálního světa a každodenní masivní útok masmédií na naše vnímání toho, co považujeme za skutečnost. Zahlceni slovy, jež často jen předstírají myšlenkový obsah, nebo přinejmenším navozují otázku, jaký smysl se za nimi opravdu skrývá, a zmateni obrazy, jež jsou provázeny protichůdnými komentáři, ptáme se naléhavě, zda existují spolehlivé zpo̊soby interpretace. Zintenzívnělé podněty z každodenní životní praxe tak aktualizují problémy, jež koncepčně rozvinula zprvu klasická filosofická hermeneutika a pak teorie interpretace vůbec.

K předpokladům interpretace nějakého sdělení náleží kromě ohledu na základní principy výkladového umění (především vědomí hermeneutického kruhu, vztahu předběžného porozumění a významového horizontu, jenž se tím otevírá, pochopení hledaného smyslu jako dění, rozpoznávání záměru, znalost pojmového pozadí, ujasnění hlediska a dialogického charakteru řeči, to vše v rámci lopotné snahy zahlédnout pod vnějším vyjádřením skrytou „vnitřní řeč“) nezbytnost ozřejmit si povahu odlišných forem znakových struktur, do nichž je smysl vepsán, a možnosti, jež pro naše chápání z toho vyplývají. Takovými formami jsou slovo a obraz, jimiž usilujeme vystihnout to, co je obsahem našeho myšlení a našich představ.

Chceme se pozastavit nad spojitostmi určujícími možnosti interpretace právě $\mathrm{v}$ těchto formách a využít při tom zejména podnětů $\mathrm{z}$ děl prof. Zdeňka Mathausera (především konceptů z prací Mezi filosofii a poezií a Estetické alternatioy (Jazyk vědy a jazyk poezie), ${ }^{1}$ hlavně co se týče vztahu jazyka vypovídajícího o obraze a obrazových reálií i vysoce inspirativní myšlenky „paralelní kontemplace“. Chtělo by se pozastavit i nad dalšími nejblíže bytujícími Mathauserovými charakteristikami jazyka zážitkového a jazyka pojmového a proměn poměru slovního jazykového znaku a obrazu, to však přesahuje možnosti tohoto příspěvku. Zároveň však chceme uplatnit i poukazy k sledovaným tematickým okruhům, jež poskytují filosoficky fundované výtvarné projevy René Magritta.

Myšlenou skutečnost lze vyjádřit slovem nebo obrazem, zároveň však můžeme interpretovat slova obrazy a naopak obraz slovy. Zvláštní pozici potom mají slova v obraze jako „asambláž“ obou forem.

Zdá se že nejjednodušší vztahy mohou nastat, když - řečeno Magrittovými slovy - „předmět se setkává se svým obrazem“ a zároveň „se předmět setkává se svým pojmenováním; tak obraz a pojmenování objektu se potkávají navzájem.“2 Blíže však lze rozpoznat komplikovanější souvislosti.

\footnotetext{
${ }^{1}$ Mathauser, Z.: Mezi filosofií a poezií, Filosofia, Praha 1995; týž: Estetické alternativy (Jazyk vědy a jazyk poezie), Gryf, Praha 1994.

2 Viz Gablik, S.: Magritte, Thames and Hudson, London 1992, s.132, obr. 4.
} 
1) Při vyjádření myšleného obsahu slovem jde o označení, pojmenování, jež v kontextu vystupuje jako chápání, oč běží, a samo teprve vymezuje „skutečnost pro nás“. Slova jako označení jsou v zásadě konvenční. Slovo v kontextuálním užití je samo interpretací tím spíše, že vychází z lexikálního celku (langue) a aplikuje se v řečovém aktu (parole) na to, s čím se ve zkušenosti setkáváme. Házíme na to připravenou sít jazykového systému a podle kontur té sítě se domníváme, že víme, co jsme do ní zachytili, neboli chtěli jí vyjádřit. Zpravidla, jak upozorňuje ve svém pojednání SLOVA A OBRAZY z r. 1929 Magritte, předmět nemá takové jméno, že by pro něj nebylo možné najít lepší. ${ }^{3}$ Přesto je možné, že existují předměty, jež nás míjejí beze jména. ${ }^{4}$ Klade se otázka, nakolik $\mathrm{v}$ takovém př́padě jde o objekty vůbec nepojmenované, nebo jen dočasně neurčité a proto bez aktuálně užitého pojmenování, či pouze aktuálně nevnímané, takže jméno nevystupuje v mysli. Nebot' vše, co vnímám, usiluje v mé mysli o pojmenování.

Pojmenování musí být, jak známo, uvedeno do vztahu, do kontextu, nebot' musíme souhlasit s Nietzschem, že neexistují fakta, nýbrž interpretace. Tuto okolnost má zřejmě na mysli Magritte, když říká: „slova, jež slouží k označení dvou rozdílných předmětů [ještě samy o sobě] neukazují, co může tyto předměty od sebe odlišovat: osoba ztrativší pamět', tělo ženy. " 5

Magritte rovněž připomíná, že slovo někdy slouží jen k tomu, aby označovalo sebe sama. ${ }^{6} \mathrm{~V}$ jeho nákresu to vypadá jako viněta připjatá k objektu, lze si však tuto verzi představit i jako případ iluzorního, vyprázdněného významu, slovo rozené v samospádu abstrakce vyjadřování, u něhož by interpretace zjistila, že za ním $\mathrm{v}$ daném řečovém kontextu nestojí žádná věcně obsahová realita. $Z$ takových slov jsou sestavovány mnohé politické proklamace. Obecnější formulaci této varianty uvádí i Magritte sám: „slovo může ve skutečnosti zaujmout místo objektu. “ 7

2) Vyjádření myšleného (představovaného) obsahu obrazem je při vší své vizuální konkrétnosti jistou abstrakcí žité skutečnosti. Skutečnost před námi vystupuje jako scény předmětů a dějů, obraz se tak bezprostředněji váže k životní zkušenosti. Je touto zkušeností jako aktuální vidění-představa toho, co je přede mnou (co je mým tématem), a její výběrovou paralelou, je-li obrazem vytvořeným z prvků známých z těchto představ. Skutečnost se mi dává v obrazech opět jako „skutečnost pro nás“; navíc vytvořené obrazy jsou interpretací tohoto vidění ve svém svérázném vizuálním jazyce, jenž postihuje smyslové hodnoty. K pochopení dalších hodnot

\footnotetext{
3 Tamtéž, obr. 1.

4 Tamtéž, obr. 2

5 Tamtéž, s. 133 , obr. 10

6 Tamtéž, s. 132, obr. 3

7 Tamtéž, obr. 6.
} 
(např. co je dobré a co špatné ve výjevech na obrazech, v dějích předkládaných televizní obrazovkou apod.) již potřebuji slovní interpretaci.

Při tom všem fakticita originálního objektu a fakticita zobrazení jsou odlišného řádu. Jak umělec uvádí, „předmět neplní nikdy tutéž funkci jako jeho jméno nebo obraz" ${ }^{8}$ To patrně připomíná Magritte také výrokem o tom, jak vše nasvědčuje, že se můžeme domnívat, že předmět a to, co jej zobrazuje (reprezentuje), mají málo společného. ${ }^{9}$

Obrazová interpretace předmětného světa se pohybuje od vizuální věrnosti po abstrakci na jedné straně a fantaskní skladbu na straně druhé. Ve všech variantách tvoří svébytné celky. To je vyjádřeno v poukazech, že „jakýkoli tvar může nahradit obraz předmětu“10 a že „viditelné obrysy předmětů se ve skutečnosti navzájem dotýkají (překrývají), až tvoří mozaiku“. ${ }^{11}$

Ve smyslovém obrazném vnímání dochází k rozpoznávání a interpretaci tvarovou analogií, sdružováním soběpodobných útvarů do souborů identit. Aktualizuje se tu problém analogie a fraktálů, představujících svébytný řád $\mathrm{v}$ domnělém chaosu. ${ }^{12}$ Ostatně Magritte si zřejmě po svém tuto okolnost uvědomoval, když si poznamenal, že „nejasné, vágní figury mají nutný a perfektní význam jako ty figury přesné“. ${ }^{13} \mathrm{~A}$ na jiném místě dodává: "Zpravidla připisujeme podobnost věcem, jež mají nebo nemají společnou povahu. Ř́káme: podobají se jako dva hrášky v lusku a stejně tak snadno řekneme, že imitace se podobá originálu. Tzv. podobnost se ustavuje srovnáním, v němž podobnosti jsou vnímány myslí v důsledku zkoušení, hodnocení, srovnávání...Podobnost se netýká souhlasu se ,zdravým rozumem' nebo vzdoru vůči němu, ale vzniká jen spontánním seskupením tvarů jevového světa do řádu daného inspirací." 14

Uspořádávání světa v mysli podle tvarových analogií, soběpodobných útvarů, vystihuje Magritte také v obraze EUKLIDOVSKÉ PROCHÁZKY: je tu scenérie, v níž část výhledu ven je zakryta plátnem, na němž je vyobrazen předpokládaný vzhled oné zakryté části. To je jedna z verzí umělcova výtvarného vtipu, který ještě připomeneme záhy $\mathrm{v}$ další souvislosti. Byl sem však vřazen nový prvek - tvar ulice se podobá tvaru kuželovité věže; rozdílné obrazy vzaté společně tvoří $\mathrm{v}$ mysli analogie. Podle B. Russella matematika vznikla, když někdo shledal, že párek

\footnotetext{
${ }^{8}$ Tamtéž, s. 134, obr. 14.

${ }^{9}$ Tamtéž, s. 133, obr. 9.

10 Tamtéž, s. 134, obr. 13.

11 Tamtéž, s. 134, obr. 15.

12 Viz Vaněk, J.: K estetice fraktálů, in: Chaos, věda a filosofie, Filosofia, Praha 1999, s. 66-87; viz též Vaněk, J.: Způsoby estetického prožívání, Galerie Zdeněk Sklenář, Praha 2009, s. 73-80.

${ }^{13}$ Viz Gablik, S.: cit. d., s. 134, obr. 16.

14 Tamtéž, s. 137.
} 
bažantů a dvojice dnů má cosi společného, totiž číslo 2. Insight je forma gestaltu, v němž náhlá aktivní percepce navozuje nové spojitosti. Je strukturována jednotou mentálního a vizuálního vjemu a právě na tom jsou založeny Magrittovy nejlepší obrazy. 15

Obraz skutečnosti si vytváříme domýšlením toho, co reálně postřehujeme. Filosoficky zdůvodněným žertem to Magritte vyjádřil obrazem PLNÁ MOC (BLANKET S PODPISEM BIANCO). Autor o tomto svém díle napsal: "Amazonka, žena na koni. Pohybuje se a skrývá se. Viditelné věci jsou vždy schopny skrývat jiné viditelné věci. Žena skrývá 4 stromy, další 3 stromy zakrývají ji. Název je svolením, které je jí dáno, aby činila, co činí.“ 16 A ještě k tomu: „Viditelné věci nemusejí být vidět. Když někdo jede na koni lesem, nejprve jej lidé vidí, za chvíli zase ne, ačkoliv vědí, že tam kůň s jezdcem jsou. V Blanketu s podpisem bianco (Plná moc) jezdkyně zakrývá stromy a stromy zase kryjí ji. Nicméně síla našeho myšlení přeskakuje jak viditelné, tak neviditelné - já jsem použil obraz, abych učinil myšlení viditelným." 17

Domýšlení se netýká jen viděného, ale také toho, co předpokládáme ve vztahu k viděnému: „předmět může naznačovat, že za ním jsou jiné předměty“18 Poukaz ke skrytosti, jež ve své neurčitosti je hrozbou čehokoli možného, má Magritte obsažen i ve svém známém obraze (namalovaném v mnoha variantách) LIDSKÁ SITUACE I (LIDSKÁ PODMÍNKA, LA CONDITION HUMAINE). Bylo řečeno, že autor zde naléhavě formuluje kontradikci mezi trojrozměrným prostorem, v němž se nalézají reálné věci, a dvoudimenzionálním prostorem plátna, které je zobrazuje. Výraznou jednoduchostí je vystižena dvojznačnost: cosi neslučitelného v konfrontaci reálného prostoru a prostorové iluze. Podle Gablikové tu Magritte definoval celou složitost moderního umění, jež vede k znehodnocení imitace př́rody. ${ }^{19}$

Zároveň tady malíř uplatnil i svůj častý prostředek: "obraz v obraze“ jako kontrapozici renesanční malby pojímané jako „okno do reality“. Korelace dvou jevů tu slouží k vyjádření styčné plochy mezi subjektivním a objektivním i jako poukaz k rozptylu identit mezi vnitřním a vnějším světem. ${ }^{20}$ Malír se při slovním popisu obrazu sám vyslovil k svému řešení fenoménu okna: „Umístil jsem před okno viděné zvnitřku místnosti, malbu zobrazující přesně tu část krajiny, již malba ve výhledu zakrývá. Takže strom zobrazený na malbě zakrývá ten strom, jenž je za ním, venku.

\footnotetext{
15 Viz tamtéž, s. 97.

16 Meuris, J.: René Magritte, Konecky \& Konecky, New York 1988, s. 174.

17 Paguet, M.: René Magritte (Thought Rendered Visible), Benedikt Taschen, Köln 1994.

18 Gablik, cit. d., s. 133 , obr. 8.

19 Viz tamtéž, s. 75.

20 Viz tamtéž, s. 86.
} 
Tak to také existuje pro diváka současně v jeho mysli: jak v místnosti, tak venku v reálné krajině. Což je právě tak, jak vidíme svět: nahlížíme na něj, jako by byl mimo nás, ačkoliv je to jen jeho mentální zobrazení, jež zakoušíme ve svém nitru. Stejným způsobem někdy umist́ujeme do minulosti to, co se stalo $\mathrm{v}$ př́tomnosti. Čas a prostor tak ztratí svůj zhrubělý význam, který jedině bereme v úvahu při každodenní zkušenosti. “ 21

Nicméně oproti stávajícím interpretacím, včetně autorské, lze ještě naznačit další: vůbec nemusí být jisté, že v zakrytém prostoru za namalovaným obrazem v obraze je přesně to, co by bylo př́mým pokračováním prostoru nezakrytého. To je jen naše zautomatizované očekávání, prolongace a extrapolace viděného. Skryté tam však může být cokoli jako neustále se připomínající existenciální ohrožení neznámým.

3) Interpretace slova prostřednictvím obrazů se může pohybovat v rozpětí od pouhé ilustrace po souběžné sdělení (což je též svého druhu „paralelní kontemplace“ - Mathauserův termín užitý vodlišné souvislosti) v obrazové formě. Verze souběžného sdělení přnináší sebou okolnost, že víceznačnosti slov lze reprezentovat rozličnými obrazy odpovídajícími různým významům. Zároveň lze obrazovou skladbou smyslově př́istupných významů a jejich interferencí sdělit tuto víceznačnost rázem, najednou, simultánně, právě skrze interferenci dílčích položek a při zapojení vnějších významových kontextů (přístup interpreta, jeho perspektiva, již zaujal z různých důvodi̊) ovlivňujících volbu spíše té či oné interpretace. Tak obrazy mohou vyjadřovat více než slova chápaná jen $v$ jejich popisné funkci, i v př́ipadě, že jde pouze o zobrazení známých prvků skutečnosti. Jsou-li ovšem slova užita a(nebo) vnímána metaforicky, mohou plnit obdobnou roli jako obrazy interferenčním vnímáním, a to zřejmě i tehdy, nenesou-li právě obraznost, ale jen její abstraktnější verzi, totiž názornost (v podobě tvarové analogie).

4) Interpretace obrazu slovy nastoluje Mathauserem vystižený problém vztahu jazyka vypovídajícího o obraze a obrazové reálie. Jde tu o rozpětí od slovy vyjádřené narativnosti až po samostatné vystižení nového prvku obraznosti v moderním umění jeho objevným slovným pojmenováním.

U zpodobení scény se zdá, že zřetelnost výjevu oproti slovu je jednoznačnější, leč skrytost smyslu oproti slovnímu vyjádření obsahuje mnohoznačnější možnosti, dokud interpretace nevysvětlí, kdo je kdo. Tak je tomu u klasických děl, ale i u obrazových dokumentů a zpráv, kupř. v televizních novinách: neznáme smysl, dokud nám není podáno vysvětlení (které může být přiměřené, ale i matoucí). Slovní výklad může být ochuzením, jde-li o umění, ujasněním, jde-li o dokumentární obraz.

21 Tamtéž, s. 87. 
Nicméně v jistém smyslu zase slovo ujasňující význam $\mathbf{v}$ určitém významovém směru je dopovězením, rozvinutím této zvolené linie smyslu; může vyjádřit víc, než stačí říci sám obraz, třebaže v jednom směru, tedy přece jen jednoznačněji. Obraz se tak stane zřídlem jednostranněji dořečené inspirace (slovní interpretací). Zvlášt' příhodný je ovšem přistup, který navrhuje Mathauser pod názvem „paralelní kontemplace“, jež svébytnou feno-menologickou reflexí dobývá po svém, svými slovesnými prostředky ono území smyslu, kam ji navedlo obrazové dílo. ${ }^{22}$ Vzorem tu je Heideggerův interpretační přístup: „slovesný výklad obrazu zde nechce být suplováním vlastní výtvarnosti obrazu: chce být jen přibližováním se k výtvarnosti obrazu! "23

Dodejme, že interpretační možnosti se budou lišit také podle toho, přečteme-li obrazové poselství jako typ nebo metaforu či symbol, anebo mýtus. ${ }^{24}$

5) Zvláštní situaci ve vztazích mezi sledovanými formami vyjádření je slovo v obraze. Může mít funkci náhražky zobrazení - Magritte tuto polohu charakterizuje slovy: „někdy pojmenování předmětu zaujímá místo obrazu ${ }^{25}$ Malíř to mnohokráte vyjadřoval svými obrazovými hříčkami, např. na obrazech STROM VĚDY či PALÁC OPON III. V takovém př́ípadě slovo není redukcí možné představivosti (jako když simultánnost a interferenčnost významů je ochuzena jednoznačnou slovní interpretací), ale naopak si jeho prostřednictvím můžeme představit rozmanité vizuální (obrazové) konkretizace. Skrze slovo umístěné do obrazu se tak aktualizuje to, co je vlastně způsobem fungování literatury vůbec.

Teoreticky je možné, i když málo pravděpodobné, opačné řešení, jež ovšem pro jistotu Magritte rovněž jmenuje: „obraz může zaujmout místo slova ve výroku“ 26 Proč to nepřipustit, když, jak malíř také připomíná, „na obrázku mají slova tutéž podstatu jako obrazy“27 Ano, jsou to dvojrozměrné znaky, avšak přesto „obrazy a slova na obraze jsou vnímány odlišně“ 28

I v této souvislosti se vyjevuje, že zástupné slovo může vyvolat neurčitější představy, ale také širší varietu představ oproti pevným tvarům již hotového vyobrazení. „Někdy pojmenování vepsaná do obrazů označují věci precisně a obrazy

\footnotetext{
22 Viz blíže Mathauser, Z.: Estetické alternativy, cit. vyd., s. 30-36.

${ }^{23}$ Mathauser, Z.: Mezi filosofii a poezii, cit. vyd., s. 95.

${ }^{24}$ K významovému rozlišení těchto myšlenkových „figur“ viz např. Vaněk, J.: Způsoby estetického prožívání, cit. vyd., s. 96-116.

25 Gablik, cit. d., s. 132, obr. 5.

26 Tamtéž, s. 133, obr. 7.

27 Tamtéž, s. 133, obr. 11.

28 Tamtéž, obr. 12.
} 
je zachycují vágně, nebo naopak“ ${ }^{29}$, tedy v takových př́ípadech jsou pojmenování vágní, obrazy přesné.

Slovo v obraze může mít i funkci napojení na realitu, jejíž součástí text je: taková funkce je připisována novinovým ústřižkům, vlepovaným kubisty do obrazů abstraktně traktované reality.

Stačili jsme naznačit jen některé základní vztahy, jež spoluurčují možnosti interpretace při užití slovesného nebo obrazného jazyka a také při jejich vzájemné součinnosti. To vše se podílí na vymezování a posouvání významových horizontů lidského světa.

29 Tamtéž, s. 134, obr. 17 a 18. 


\section{Obrazový doprovod}

Un objet ne tient pas tellement à son nom qu'on ne puisse lui en trouver un autre qui lui convienne mieux :

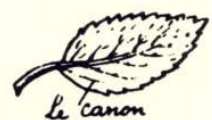

Il $\mathbf{y}$ a des objets qui se passent de nom :

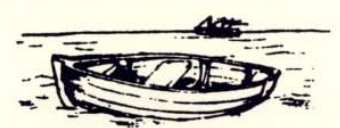

Un mot ne sert parfois qu'à se désigner soi-même :

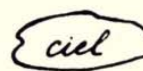

Un objet rencontre son image, un objet rencontre son nom. Il arrive que l'image et le nom de cet objet se rencontrent :

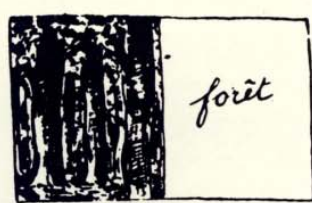

Parfois le nom d'un objet tient lieu d'une image :

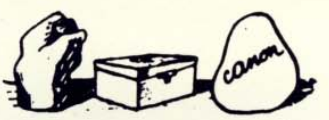

Un mot peut prendre la place d'un objet dans la

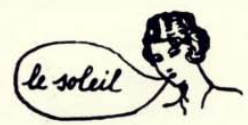

Une image peut prendre la place d'un mot dans une proposition :

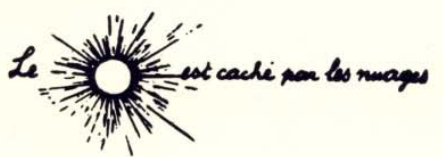

Un objet fait supposer qu'il y en a d'autres derrière

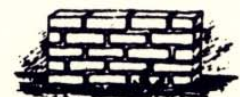

Tout tend à faire penser qu'il $\mathbf{y}$ a peu de relation entre un objet et ce qui le représente :

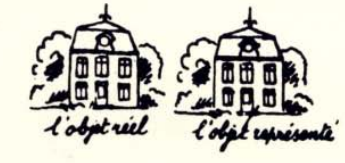

Les mots qui servent à désigner deux objets différents ne montrent pas ce qui peut séparer ces objets l'un de l'autre :

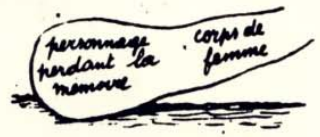

Dans un tableau, les mots sont de la même substance que les images :

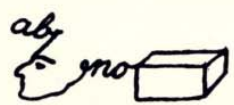

On voit autrement les images et les mots dans un tableau :

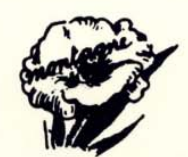

Une forme quelconque peut remplacer l'image d'un objet :

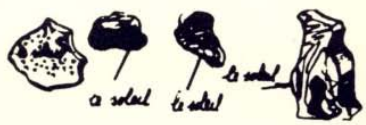

Un objet ne fait jamais le même office que son nom ou que son image :

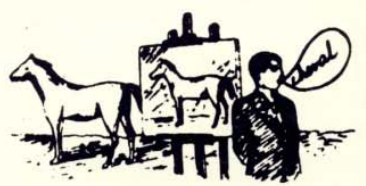

Or, les contours visibles des objets, dans la réalité, se touchent comme s'ils formaient une mosaique :

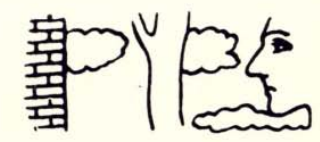

Les figures vagues ont une signification aussi nécessaire, aussi parfaite que les précises :

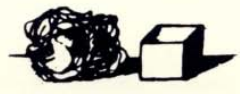

Parfois, les noms écrits dans un tableau désignent des choses précises, et les images des choses vagues :

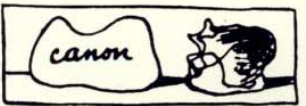

Ou bien le contraire

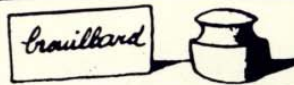

Rene Maourm.

René Magritte, SLOVA A OBRAZY, 1929. Obr. 1-18 ve třech řadách, počítány vždy odshora dolů (1-6,7-12,13-18). 


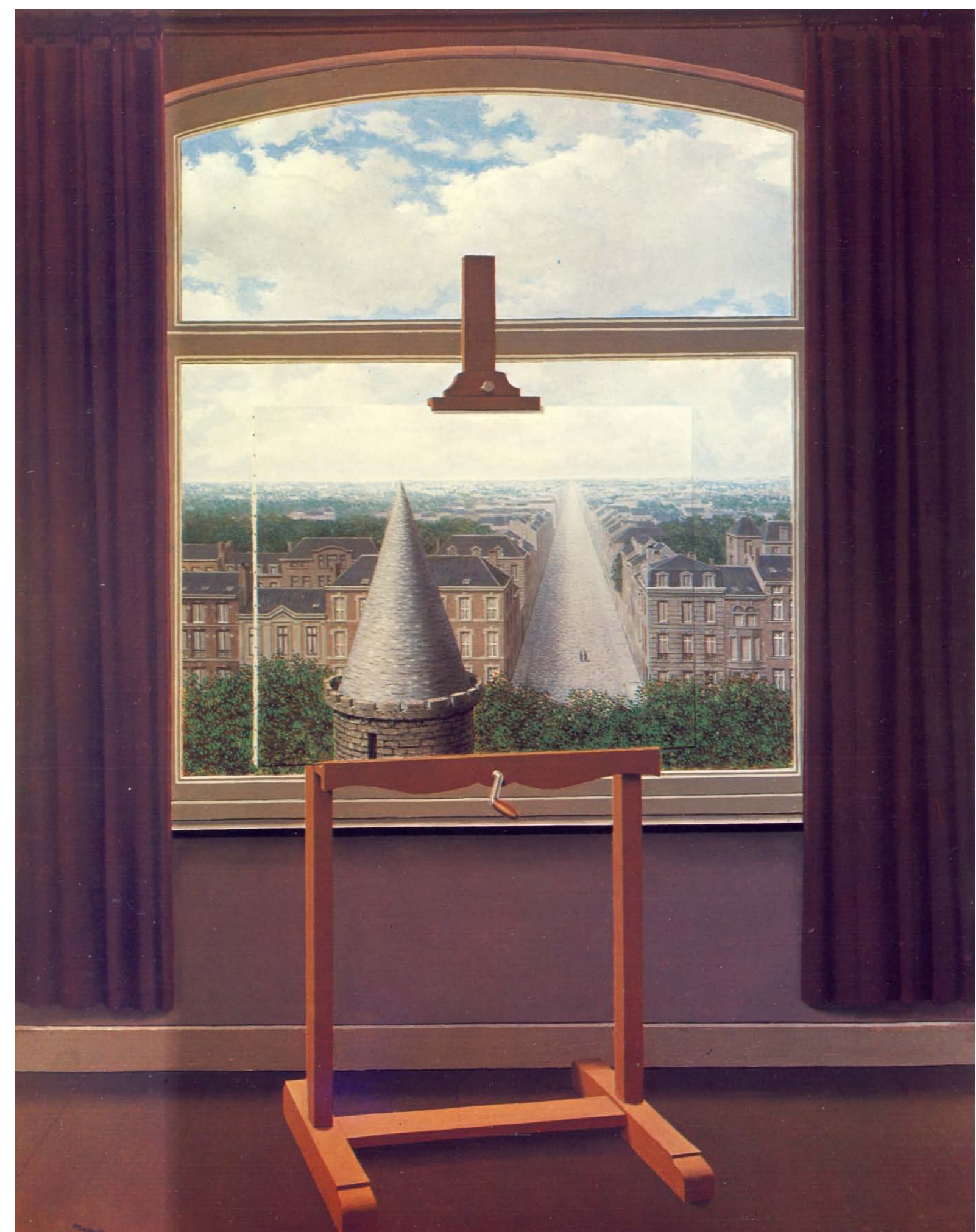

René Magritte, EUKLIDOVSKÉ PROCHÁZKY, 1955 


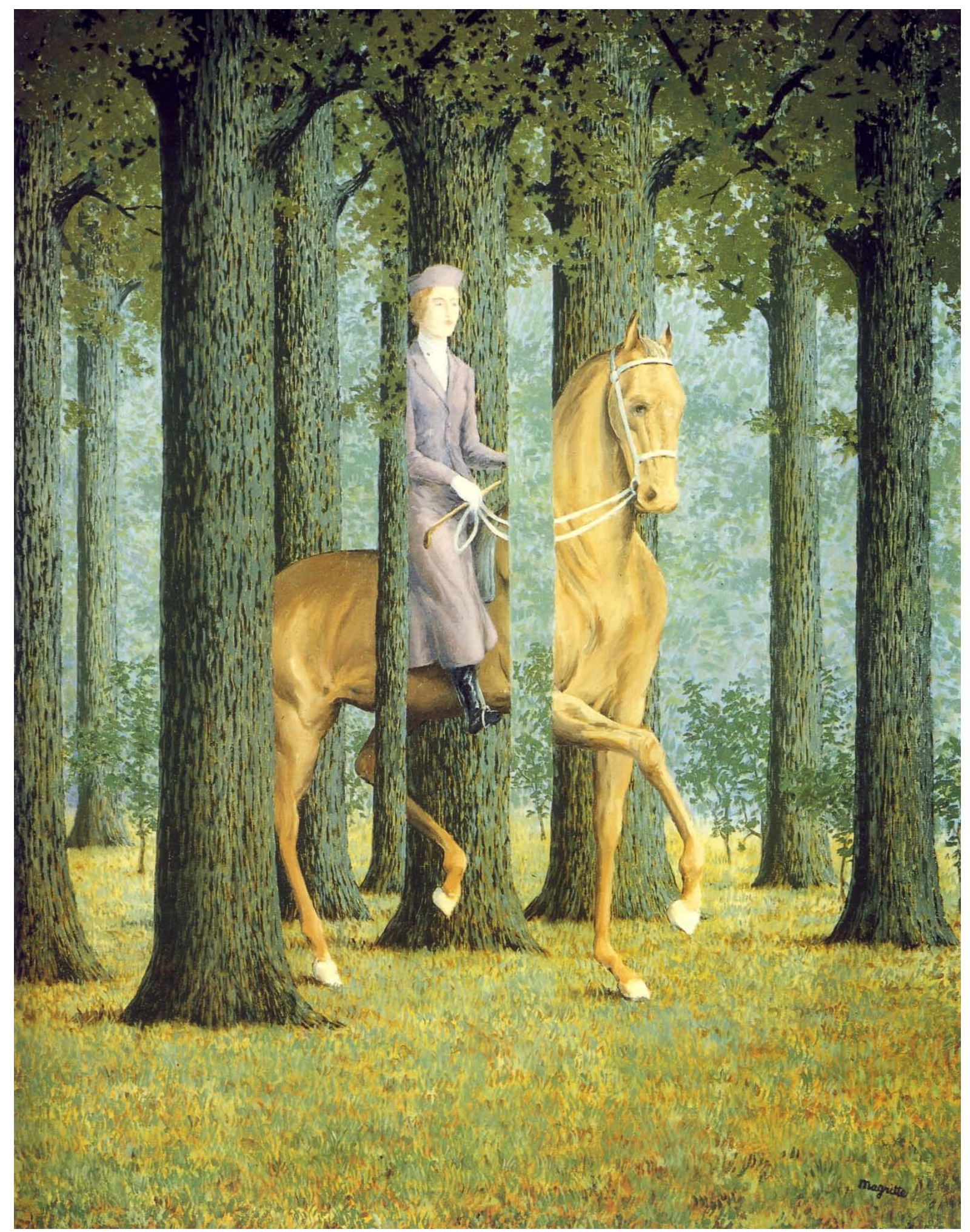

René Magritte, PLNÁ MOC (BLANKET S PODPISEM BIANCO), 1965 




René Magritte, LIDSKÁ SITUACE I (LIDSKÁ PODMÍNKA, LA CONDITION HUMAINE), 1933 


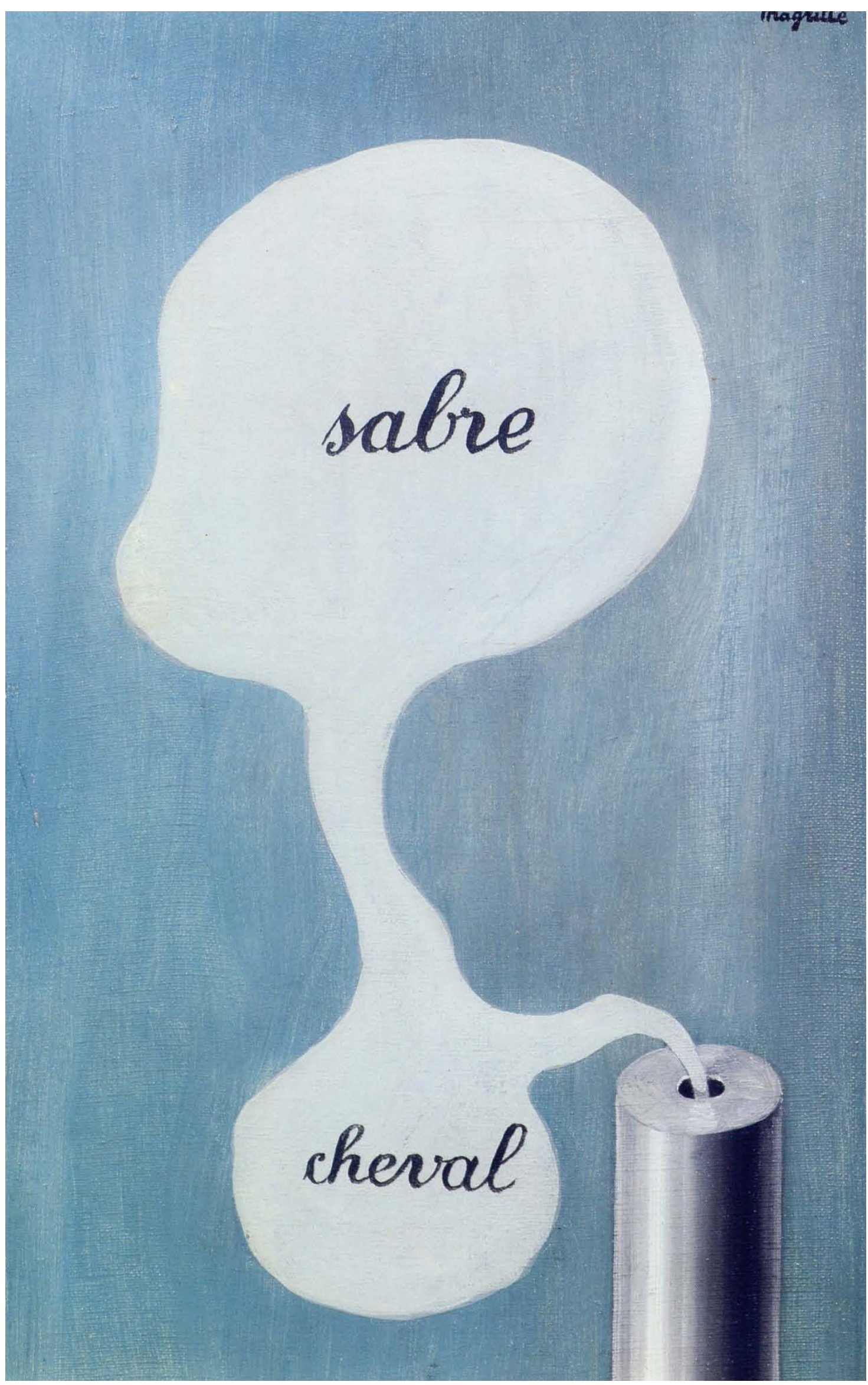

René Magritte, STROM VĚDY, 1929 


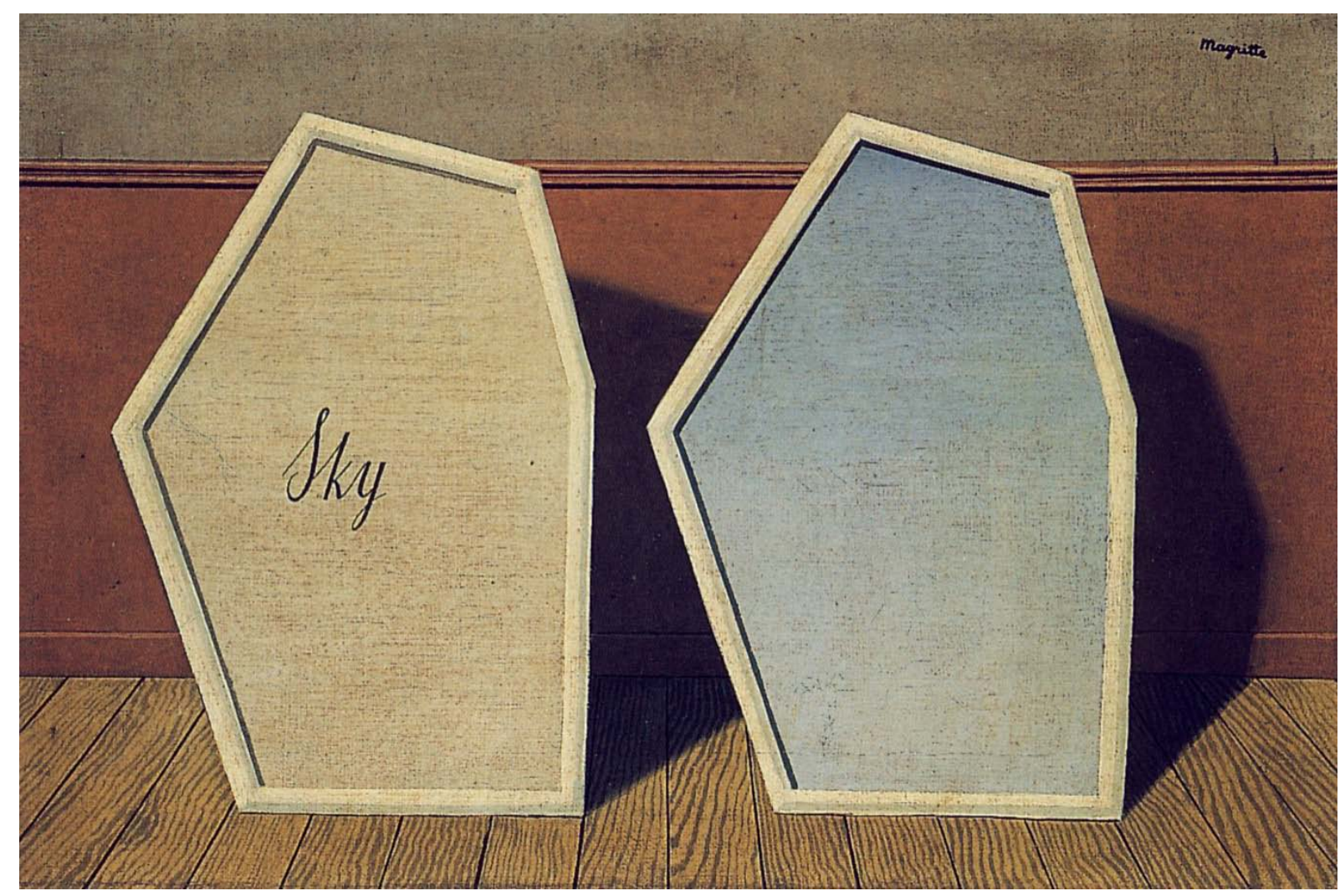

René Magritte, PALÁC OPON III, 1936 


\section{Bibliography}

Mathauser, Z.: Mezi filosofií a poezií, Filosofia, Praha 1995.

Mathauser, Z.: Estetické alternativy (Jazyk vědy a jazyk poezie), Gryf, Praha 1994.

Gablik, S.: Magritte, Thames and Hudson, London 1992.

Vaněk, J.: K estetice fraktálů, in: Chaos, věda a filosofie, Filosofia, Praha 1999.

Vaněk, J.: Způsoby estetického prožívání, Galerie Zdeněk Sklenář, Praha 2009.

Meuris, J.: René Magritte, Konecky \& Konecky, New York 1988.

Paguet, M.: René Magritte (Thought Rendered Visible), Benedikt Taschen, Köln 1994. 


\section{E- LOGOS}

\section{ELECTRONIC JOURNAL FOR PHILOSOPHY}

Ročník/Year: 2009 (vychází průběžně/ published continuously)

Místo vydání/Place of edition: Praha

ISSN 1211-0442

Vydává/Publisher:

Vysoká škola ekonomická v Praze / University of Economics, Prague

nám. W. Churchilla 4

Czech Republic

13067 Praha 3

IČ: 61384399

Web: http://e-logos.vse.cz

Redakce a technické informace/Editorial staff and technical information:

Miroslav Vacura

vacuram@vse.cz

Redakční rada/Board of editors:

Ladislav Benyovszky (FHS UK Praha)

Ivan Blecha (FF UP Olomouc)

Martin Hemelík (Masarykovo klasické gymnázium, Řičany u Prahy)

Angelo Marocco (Pontifical Athenaeum Regina Apostolorum, Rome)

Jozef Kelemen (FPF SU Opava)

Daniel Kroupa (ZU Plzeň)

Vladimír Kvasnička (FIIT STU Bratislava)

Jaroslav Novotný (FHS UK Praha)

Jakub Novotný (Vysoká škola polytechnická, Jihlava)

Ján Pavlík (editor-in-chief) (VŠE Praha)

Karel Pstružina (VŠE Praha)

Miroslav Vacura (executive editor) (VŠE Praha) 